\title{
Influence of biologically active agents of vegetable origin in comparison with antibiotics upon bees at nosematosis
}

\author{
H. V. Odnosum, \\ postgraduate student \\ National University of Life and environmental Sciences of Ukraine \\ N. M. Soroka, \\ Doctor of Veterinary Medicine, Professor \\ National University of Life and environmental Sciences of Ukraine \\ T. M. Yefimenko, \\ PhD in Biology \\ NSC «Institute of Beekeeping named after P.I. Prokopovich»
}

The purpose. To study possibility of improvement of bees at nosematosis by biologically active agents of vegetable origin in comparison with the most spread anti-nosematosis specimens on the basis of antibiotics. Methods. Research is carried out on summer generation of even-aged flight bees with artificial inoculation by Nosema sp. (5.104 spores for a bee). Investigated materials were fed on $11^{\text {th }}$ and $18^{\text {th }}$ day after the moment of infestation. Results. Influence is determined of specimen KAS-81 and its components, as well as Fumagilin and Nozemat upon dynamics of death of bees with nosematosis and level of their infestation by spores of Nosema sp. in laboratory conditions. Conclusions. Feeding with vegetable specimen KAS-81 and its components, and also specimens on the basis of antibiotics (Fumagilin and Nozemat) slow down death of bees infected by spores of Nosema $s p$. in comparison with control (septic bees were not treated up to the end of their natural death). The most effective among the probed matters has appeared specimen KAS-81.

Key words: nosematosis, Nosema apis, Nosema ceranae, biologically active agents, KAS-81, pine bud, wormwood, dynamics of death, treatment.

Nosema disease (nosemosis) - the disease of honeybees, which causes significant economic losses to beekeeping. Nosemosis is widespread on all continents where bees are multiplied. Very common and harmful in the apiaries in Ukraine is nosemosis. Nosema apis [1, 6, 12] and Nosema ceranae [4, 7] obligated intracellular parasites.

For the treatment and prevention of Nosema disease in beekeeping, traditionally have been used and still used in some countries antibiotics based on the products of vital activity of the fungus Aspergillus fumigatus $F$. These are drugs such as fumagillin and its analogues (Fumagillin-DCG, Fumagillin-B, etc.) that are still used in the United States, Canada, Latin America. They can be bought via the Internet also by the beekeepers in Ukraine. However, in Ukraine and the countries of the CIS against nosemosis most commonly used in our time mainly drugs, the active substances of which are oxytetracycline and metronidazole (Nozemat, Nosemacid, Nosetom, etc.), which are recommended for the feeding with spring food, and less often, for the prevention of the disease in the fall.

Because of the high cumulative effect and negative side effects (reduction of immunity in animals and humans, the emergence of resistant strains of pathogenic microorganisms), antibiotics and chemical preparations used nowadays in beekeeping very limited. The European countries - the main importers of Ukrainian honey, have banned the use of antibiotics, sulfanilamide and other drugs for the prophylactic and treatment of bees from diseases (EU / 3/01/081). Nowadays this is a huge problem for countries, which export honey to Europe. It is known that honey from Ukraine is often banned due to the presence of antibiotics, sulfanilamide, nitrofurans in it [9].

Given that antibiotics are prohibited for use in beekeeping in European countries - the main importers of Ukrainian honey, experimental confirmation of the possibility of complete refusal of antibiotics for the 
treatment and prophylactic of bees from Nosema disease and its replacement on the preparations of biological origin is relevant.

The study aims to investigate the possibility of bees healing from Nosema disease by ecologically safe means of plant origin.

The objective of the study was to compare the effect of bees feeding of biologically active substances (BAS) of the plant origin (plant preparation KAS-81 (0,35\%) and its components - pine bud extract Pinus sylvestris L. $(0,0175 \%)$ and wormwood Artemisia absinthium L. ( $0,3325 \%))$ and the most common preparations based on antibiotics (Fumagillin-B and Nozemat according to the manufacturer's instructions) on the dynamic of bee extinction at Nosema disease and their degree of invasion by the spores of Nosema $s p$. under the laboratory conditions.

Material and methods. The experiment was conducted on the summer generation of one-aged bees (12 - 13 day from the moment of rebirth). After the selection, bees were placed into the study cages, and were infected by the spores of Nosema sp. in a dose of $5 \times 10^{4}$ spores per one bee by feeding with $50 \%$ sugar syrup. On the 3-rd day, sugar syrup was added without spores of the pathogen. The invastigared substances were fed twice - on the 11th and 18th day after invasion. In the experiment, two control variants were provided: bees with an invasion (sick) without the feeding of preparations and bees without invasion and without feeding of the preparations (conditionally healthy). Bees account was kept every $2-3$ days. Experimental bees were kept in study cages by 50 pcs. in each ( 1 cage -1 repeat, 150 bees per variant) in a thermostat at a temperature of $27^{\circ} \mathrm{C}$ and a relative humidity of $70-85 \%$. Syrup was added to the extent of its use. For invasion were used spores of Nosema $s p$., which where previously allocated from the bees midgut by known methods [3].

The cause of insect mortality was determined by the prevailing microflora on smears from the intestines of bees after specific staining on different groups of entomopathogens [2]. The influence of preparations on the degree of bee invasion by spores of Nosema sp. were determined by the scale of O. F. Grobov (1989) [5]. Influence of preparations on the vegetative stages of $N$. apis ( $N$. ceranae) was determined by smears painted after the Romanovsky-Gimza method[11].

Results. The dynamic of bees' extinction under the condition of two-time feeding with sugar syrup of plant aqueous extracts (the preparation KAS-81 and its components, namely the wormwood and pine buds) in comparison with Fumagillin-B and Nosemat are presented in table 1 and figure 1.

Table 1. Influence of the plant based preparations and antibiotics on bees extinction at Nosema disease $(M \pm m, n=3)$

\begin{tabular}{|c|c|c|c|c|c|c|c|c|c|c|}
\hline \multirow{2}{*}{ Variant of the experiment } & \multicolumn{10}{|c|}{ Extinction per day of account, \% } \\
\hline & 11 & 22 & 35 & 49 & 56 & 63 & 71 & 78 & 85 & 91 \\
\hline $\begin{array}{c}\text { Variant 1. Bees without } \\
\text { invasion and without } \\
\text { treatment, conditionally } \\
\text { healthy (control) } \\
\end{array}$ & 0 & $\begin{array}{c}1,3 \\
\pm 0,67\end{array}$ & $\begin{array}{c}2,7 \\
\pm 0,67\end{array}$ & $\begin{array}{c}12,7 \\
\pm 0,67\end{array}$ & $\begin{array}{r}18,7 \\
\pm 2,91\end{array}$ & $\begin{array}{c}38,7 \\
\pm 0,67\end{array}$ & $\begin{array}{c}56 \\
\pm 2,31\end{array}$ & $\begin{array}{c}71,3 \\
\pm 5,21\end{array}$ & $\begin{array}{r}77,3 \\
\pm 5,21\end{array}$ & $\begin{array}{c}87,3 \\
\pm 4,06\end{array}$ \\
\hline $\begin{array}{l}\text { Variant 2. Bees with an } \\
\text { invasion and without } \\
\text { treatment, sick (control) }\end{array}$ & $\begin{array}{c}10 \\
\pm 1,15\end{array}$ & $\begin{array}{c}14 \\
\pm 1,76\end{array}$ & $\begin{array}{c}20 \\
\pm 1,15\end{array}$ & $\begin{array}{c}43,3 \\
\pm 6,36\end{array}$ & $\begin{array}{c}53,3 \\
\pm 6,57\end{array}$ & $\begin{array}{c}62 \\
\pm 6,11\end{array}$ & $\begin{array}{c}76,7 \\
\pm 4,37\end{array}$ & $\begin{array}{c}87,3 \\
\pm 3,71\end{array}$ & $\begin{array}{r}95,3 \\
\pm 1,76\end{array}$ & $\begin{array}{c}98,7 \\
\pm 1,33\end{array}$ \\
\hline $\begin{array}{l}\text { Variant 3. Bees with an } \\
\text { invasion and with the } \\
\text { preparation Nozemat }\end{array}$ & $\begin{array}{c}3,3 \\
\pm 0,67 \\
*\end{array}$ & $\begin{array}{c}6 \\
\pm 1,15 \\
*\end{array}$ & $\begin{array}{c}14,7 \\
\pm 1,76 \\
*\end{array}$ & $\begin{array}{c}32,7 \\
\pm 0,67 \\
* *\end{array}$ & $\begin{array}{c}44,7 \\
\pm 0,67 \\
* *\end{array}$ & $\begin{array}{c}53,3 \\
\pm 6,96 \\
*\end{array}$ & $\begin{array}{l}66,7 \\
\pm 6,57 \\
*\end{array}$ & $\begin{array}{l}77,3 \\
\pm 7,06 \\
*\end{array}$ & $\begin{array}{c}91,3 \\
\pm 2,40 \\
* *\end{array}$ & $\begin{array}{c}97,3 \\
\pm 1,76 \\
* *\end{array}$ \\
\hline $\begin{array}{l}\text { Variant 4. Bees with an } \\
\text { invasion and with the } \\
\text { preparation Fumagilline-B }\end{array}$ & $\begin{array}{c}2,7 \\
\pm 0,67 \\
*\end{array}$ & $\begin{array}{c}6 \\
\pm 1,15 \\
*\end{array}$ & $\begin{array}{c}13,3 \\
\pm 0,67 \\
* *\end{array}$ & $\begin{array}{c}31,3 \\
\pm 1,76 \\
* *\end{array}$ & $\begin{array}{c}42,7 \\
\pm 1,33 \\
* *\end{array}$ & $\begin{array}{l}50 \\
\pm 1,15 \\
* *\end{array}$ & $\begin{array}{c}62,7 \\
\pm 7,42 \\
*\end{array}$ & $\begin{array}{c}73,3 \\
\pm 5,70 \\
* *\end{array}$ & $\begin{array}{c}86,7 \\
\pm 6,36 \\
* *\end{array}$ & $\begin{array}{c}95,3 \\
\pm 3,71 \\
* *\end{array}$ \\
\hline $\begin{array}{l}\text { Variant } 5 . \text { Bees with an } \\
\text { invasion and with an extract } \\
\text { of pine buds }(0,0175 \%)\end{array}$ & $\begin{array}{c}0,7 \\
\pm 0,67 \\
*\end{array}$ & $\begin{array}{c}4,7 \\
\pm 1,76 \\
*\end{array}$ & $\begin{array}{c}12,7 \\
\pm 0,67 \\
* *\end{array}$ & $\begin{array}{c}30,7 \\
\pm 1,76 \\
* *\end{array}$ & $\begin{array}{c}43,3 \\
\pm 1,76 \\
* *\end{array}$ & $\begin{array}{c}52 \\
\pm 2,31 \\
* *\end{array}$ & $\begin{array}{c}64,7 \\
\pm 2,40 \\
* *\end{array}$ & $\begin{array}{c}71,3 \\
\pm 2,40 \\
* *\end{array}$ & $\begin{array}{c}81,3 \\
\pm 3,53 \\
* *\end{array}$ & $\begin{array}{l}94,7 \\
\pm 2,40 \\
* *\end{array}$ \\
\hline
\end{tabular}




\begin{tabular}{|c|c|c|c|c|c|c|c|c|c|c|}
\hline $\begin{array}{l}\text { Variant } 6 . \text { Bees with an } \\
\text { invasion and with an extract } \\
\text { of wormwood }(\mathbf{0 , 3 3 2 5} \%)\end{array}$ & 0 & $4 \pm 0$ & $\begin{array}{c}10,7 \\
\pm \underset{*}{ \pm 1,33}\end{array}$ & $\begin{array}{c}21,3 \\
\pm 1,33 \\
* *\end{array}$ & $\begin{array}{c}30,7 \\
\pm 1,76 \\
* *\end{array}$ & $\begin{array}{c}44,7 \\
\pm 4,81 \\
*\end{array}$ & $\begin{array}{c}60,7 \\
\pm 7,69 \\
*\end{array}$ & $\begin{array}{c}72,7 \\
\pm 8,74 \\
*\end{array}$ & $\begin{array}{c}80,7 \\
\pm 7,69 \\
*\end{array}$ & $\begin{array}{l}92,7 \\
\pm 4,06 \\
* *\end{array}$ \\
\hline $\begin{array}{c}\text { Variant 7. Bees with an } \\
\text { invasion and with the } \\
\text { preparation KAS-81 (0,35 } \\
\%)\end{array}$ & 0 & $\begin{array}{c}1,3 \\
\pm 0,67 \\
*\end{array}$ & $\begin{array}{c}3,3 \\
\pm 0,67 \\
*\end{array}$ & $\begin{array}{c}18,7 \\
\pm 0,67 \\
* *\end{array}$ & $\begin{array}{c}24,7 \\
\pm 3,71 \\
*\end{array}$ & $\begin{array}{c}39,3 \\
\pm 2,91 \\
\star *\end{array}$ & $\begin{array}{c}57,3 \\
\pm 3,71 \\
* *\end{array}$ & $\begin{array}{c}68,7 \\
\pm 5,81 \\
*\end{array}$ & $\begin{array}{c}78,7 \\
\pm 6,36 \\
\star\end{array}$ & $\begin{array}{c}87,3 \\
\pm 5,46 \\
\star *\end{array}$ \\
\hline
\end{tabular}

Notation: ${ }^{*} \mathrm{p} \leq 0,05 ;{ }^{* *} \mathrm{p} \leq 0,01$ compared to the control.

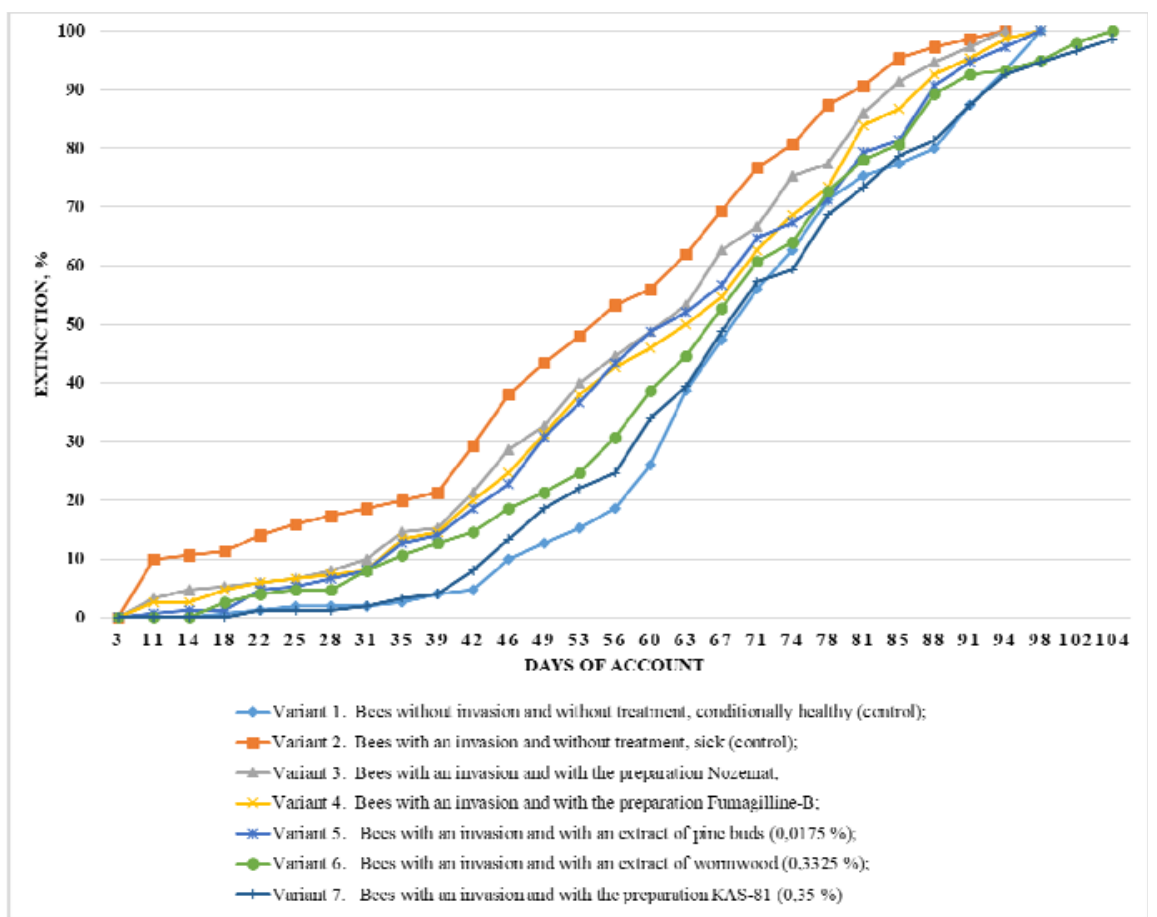

Fig. 1. Influence of the plant based preparations and antibiotics on bees extinction at Nosema disease

It was established that the feeding of the plant preparation KAS-81 (0.35\%) and its components - extracts from pine buds $(0.0175 \%)$ and wormwood $(0.35 \%)$, as well as preparations based on antibiotics - Nosemat and Fumagillin-B (doses according to manufacturers' instructions) slows (from 1,4 (97,3 $\pm 1,76 \%$ ) to $28,7 \%$ $(24,7 \pm 3,71 \%) n=3, p \leq 0,05)$ the extinction of bees, infected by the spores of Nosema $s p$. compared to the control, where infected bees were not treated until the end of their natural extinction (up to 104 days).

The most effective among all investigated substances was the preparation KAS-81, the feeding of which allowed to slow down the natural extinction of infected bees (from $0.6(3.3 \pm 0.67 \%)$ to $6 \%(24.7 \pm 3.71 \%$ ), $n=3, p \leq 0.05$ ) to the control level (healthy bees without invasion) up to 35 day of observation. Experimental bees lived in this variant longer (on $6-10$ days) than with the feeding of antibiotics. The extract from the wormwood was close to the effectiveness of the KAS-81 preparation. In these two variants experimental bees lived the longest.

Microscopic analysis of bee intestines showed that no plant extracts (a complex plant preparation KAS-81 and its components - extracts from pine buds and wormwood), nor antibiotic preparations do not eliminate spores and vegetative stages of the spores of the parasite Nosema apis (Nosema ceranae). At the same time, in variants with the feeding of antibiotics, the active spore formation of parasites is somewhat slowed down. The degree of invasion of experimental bees by the spores of Nosema $s p$. in all variants with the feeding of the studied substances was high, as in the control, where the drugs were not fed.

The wellness effect of both plant and antibiotic-based preparations, in our opinion, is due to their action as antiseptics, first of all, which have a detrimental effect on the microflora of bees intestines, which is involved in the pathological process at the Nosema disease [10], and not as drugs that can significantly affect on the development of $N$. apis (N. ceranae). 
The obtained data indicate that the antibiotics used in beekeeping against Nosema pathogens do not significantly affect on the development of Nosema sp. Similar data were also obtained by other researchers [8]. Do not inhibit the development of Nosema pathogens also plant preparations, but they significantly increase the life expectancy of sick bees, slowing down their extinction, and hence, the effect of action prevailing antibiotics. Thus, antibiotics can be replaced by plant preparations with antiparasitic, mycocidal and bactericidal effects, for example, by KAS-81 preparation, which can be easily prepared at home.

\section{Conclusions}

It was established that the feeding of the plant preparation KAS-81 $(0.35 \%)$ and its components - extracts from pine buds $(0.0175 \%)$ and wormwood $(0.35 \%)$, as well as preparations based on antibiotics - Nosemat and Fumagillin-B, slows down extinction of bees affected by Nosema sp., compared to the control, where infected bees were not treated until the end of their natural extinction (up to 104 days).

The most effective of all of the investigated substances was the preparation KAS-81. Experimental bees lived in this variant longer (in general up to $6-10$ days) than in variants with the feeding of antibiotics. The mortality rate of bees decreased from 10 to $28.66 \%$ in comparison with the control. The second on the efficiency was an extract from wormwood. In these two variants experimental bees lived the longest.

Microscopic analysis of bee intestines showed that no plant extracts, nor antibiotic preparations do not eliminate spores and vegetative stages of the spores of the parasite Nosema $s p$. The degree of invasion of experimental bees by the spores of Nosema sp. was high, as in the control, where the drugs were not fed.

Therefore, neither antibiotics, which is used as drugs against Nosema disease, nor plant extracts, significantly affect the development of Nosema sp., but the plant extracts significantly increase the life expectancy of bees affected by the spores of Nosema sp., the effect of which prevails antibiotics, which means that antibiotics can be replaced by plant preparations with antiparasitic , mycocidal and bactericidal effect, and, as an example, the use of a plant preparation KAS-81 can be effective, which can be easily prepared at home.

\section{Bibliography}

1. Alekseenko F. M., Revenok V. A., Chepurko M. A. (1991). Handbook of diseases and pests of bees. Kyiv: Urozhaj. 240 s. [In Russian].

2. Evlahova A. A. (1964). Methods of recognition of insect diseases. Moskva. $50 \mathrm{~s}$.

3. Elfimova T. F. (1985). Optimal conditions for the mass production of the spores of microsporidia Vairimorpha on Cabbage Moth. Avtoref. dis. kand. biol. nauk. Alma-Ata. 16 s. [In Russian].

4. Fries I., Feng F., Silva A., Slemenda S.B., Pieniazek N.J. Nosema ceranae n. sp. (Microspora, Nosematidae), morphological and molecular characterization of a microsporidian parasite of the Asian honey bee Apis cerana (Hymenoptera, Apidae). European Journal of Protistology. 1996. Vol.32. P. 356-365.

5. Grobov O. F., Lihotin A. K. (1989). Diseases and pests of honey bees. - Moskva: Agropromizdat. 239 s. [In Russian].

6. Grobov O. F., Smirnov A. M., Popov E. T. (1987). Diseases and pests of honey bees. Moskva: Agropromizdat. -335s. [In Russian].

7. Huang W. F., Jiang J. H., Chen Y. W., Wang C. H. (2007). A Nosema ceranae isolate from the honeybee Apis mellifera. Apidologie, Springer Verlag. -. - №38 (1). - P. 30-37.

8. Huang W., Solter L., Yau P., Imai B. Nosema ceranae Escapes Fumagillin Control in Honey Bees. March 07. - 2013.

9. Silonova N. B., Odnosum H. V. (2015). International regulation of indicators of safety and quality of beekeeping products. Materiali II Vseukraïns'koï naukovo-praktichnoï konferenciï molodih vchenih ta studentiv "Jakist' ta bezpechnist' tovariv». Luc'k. S. 84-86. [In Ukrainian].

10. Vejzer J. (1972). Microbiological methods for controlling harmful insects. - Moskva: Kolos. - $495 \mathrm{~s}$. [In Russian].

11. Voronin V. N., Issi I. V. (1974). About the methods of working with microsporidia. Parazitologija. 1974. T.8, №3. S. 272-273. [In Russian].

12. Zander E. (1909). Tierische Parasiten als Krankheitserreger bei der Biene. Leipziger Bienenzig. Leipziger Bienenzig. №24. P. 147-150. 